\title{
Effect of Light Spectrum on Gas Exchange, Growth and Biochemical Characteristics of Einkorn Seedlings
}

\author{
Maria Luce Bartucca ${ }^{1}$, Daniele Del Buono ${ }^{1, *}$, Eleonora Ballerini ${ }^{2}$, Paolo Benincasa ${ }^{1}$, \\ Beatrice Falcinelli ${ }^{1}$ and Marcello Guiducci ${ }^{1}$ \\ 1 Dipartimento di Scienze Agrarie, Alimentari ed Ambientali, Università degli Studi di Perugia, \\ Borgo XX Giugno 74, 06121 Perugia, Italy; marialucebartucca@gmail.com (M.L.B.); \\ paolo.benincasa@unipg.it (P.B.); beatricefalcinelli90@gmail.com (B.F.); marcello.guiducci@unipg.it (M.G.) \\ 2 Dipartimento di Chimica, Biologia e Biotecnologie, Università degli Studi Perugia, via Elce di Sotto 8, \\ 06123 Perugia, Italy; eleonoraballerini@yahoo.it \\ * Correspondence: daniele.delbuono@unipg.it
}

Received: 16 June 2020; Accepted: 17 July 2020; Published: 19 July 2020

\begin{abstract}
The use of Light Emitting Diode (LED) lights in microscale vegetable production is more and more widespread. In this context, the effect of light spectrum on photosynthesis, growth, shoot yield, pigment content, and nutritional status of einkorn seedlings (Triticum monoсоссит L. ssp. monососсит), germinated and grown in a nutrient solution, was investigated. Plants were subjected to six different LED light treatments, all having a photon flux density (PFD) of $200 \mu \mathrm{mol} \mathrm{m} \mathrm{m}^{-2} \mathrm{~s}^{-1}$. Two light treatments were monochromatic (red or blue), three dichromatic (blue and red in the proportion), and one of a wider spectrum (selected as a control). All the light treatments affected the morphological, biochemical, and nutritional status of einkorn seedlings. Overall, the dichromatic treatments were the most effective in stimulating biomass production, $\mathrm{CO}_{2}$ assimilation, and evapotranspiration, as well as contents in chlorophyll a and b and carotenoids, and additionally nitrogen, phosphorous, manganese, iron, and zinc. These results are of relevance for the beneficial effects of dichromatic LED treatments in maximizing einkorn shoot yield and nutritional values, and in limiting energy consumption in indoor cultivation.
\end{abstract}

Keywords: LED; net $\mathrm{CO}_{2}$ assimilation; evapotranspiration; biomass; pigments; plant nutrition

\section{Introduction}

Over the last decade, there has been a sharp increase in indoor vegetable production as it offers many advantages when compared to conventional field vegetable cultivation. This methodology is based on the growth of plants in soilless systems under controlled conditions of temperature, relative humidity, photoperiod, light intensity, and nutrient and water supply. This approach also includes limited incidences of pest and disease attacks. Furthermore, it allows for the shortening of the growing cycles and the obtaining of high-quality products. Moreover, well-designed indoor systems (e.g., hydroponics) can minimize water and nutrient inputs, as well as the use of herbicides and pesticides [1]. If properly implemented, this technology could also contribute to coping with global food demand and reducing environmental pollution $[2,3]$. Finally, indoor systems are less exposed to threats related to climate change [3].

In the production of indoor vegetables, an increasing share is represented by microscale vegetables. In this context, sprouts and microgreens of a wide range of plant species, including niche species, have gained considerable interest. In particular, they are appreciated by consumers for their unique taste, and it has been shown that they could have healthy properties $[4,5]$. 
In indoor systems, the energy supply for photosynthesis is mainly provided by artificial lights, with there being an increasingly widespread use of Light Emitting Diode (LED) lamps. LED lamps can be designed to deliver light to plants with only specific light wavelengths. This possibility allows for the improvement of light use efficiency, reducing power consumption and stimulating particular physiological and biochemical processes [3,6]. All these positive effects permit the obtaining of high yield and high-quality products at a low cost. In addition, some studies have reported that LED lights could reduce microbial contamination and improve post-harvest ripening and/or preservation of fruit and vegetables [7]. The ability of LED lights to influence crop growth and yield depends on the photoperiod, light intensity, and spectral composition [3,8].

However, the responses of the plants to these lamps are species-specific [8]. Plant light perception is managed by sophisticated photoreceptor systems that can affect growth and development. In particular, they operate by activating/inactivating and modulating very complex processes that influence the morphology, physiology, and metabolism of plants [9]. This regulation controlled by the photoreceptors also has implications on the plant uptake and use of nutrients, chlorophyll content [10], and production of secondary metabolites and antioxidants [7]. In particular, blue and red lights are more effective than other wavelengths in the specific activation of the photoreceptors in plants [11]. For instance, three families of blue photoreceptors (i.e., phototropins, cryptochromes, and phytochromes) regulate stomata opening [12]. Moreover, chlorophylls show strong absorption in the red (chlorophyll a and b at 633 and $642 \mathrm{~nm}$, respectively) and blue (chlorophyll $\mathrm{a}$ and $\mathrm{b}$ at 430 and 453, respectively) regions [13]. Furthermore, blue light allows plants to achieve normal leaf anatomy, high stomatal density, and enhanced photosynthesis [14]. On the other hand, plants cannot develop optimally with monochromatic red light alone [15].

To date, researchers have mainly focused their studies on the impact on plants of different combinations of red and blue light [3]. As for microgreens, the effects of the light spectrum have been studied for several species, including einkorn wheatgrass [16-18]. In particular, 1-2-week old shoots of einkorn seedlings, mainly used for the production of juices, showed very high polyphenol, phenolic acid, and antioxidant content $[19,20]$. Furthermore, Benincasa et al. [18] investigated the effect of light spectrum on wheatgrass that was obtained by sprouting grains with distilled water, highlighting its impact on phenolic content and antioxidant activities.

To date, however, no study has paid attention to the possibility of growing einkorn seedlings on a substrate containing a nutrient solution, in order to obtain einkorn shoots from repeated cutting. In this sense, the joint action of the light composition and changing the spectrum with a substrate containing nutritive elements would determine significant effects on photosynthesis and growth of wheatgrass, as well as on the content of pigments and nutrient uptake.

For the abovementioned reasons, this work aimed to study the effects of monochromatic blue, monochromatic red, and dichromatic blue/red lights, combined in some different blue/red proportions, on gas exchange, plant morphology and growth, pigment content, and nutrient uptake of einkorn seedlings.

\section{Materials and Methods}

\subsection{Plant Material, Growth Conditions, and Light Treatments}

Einkorn seeds (Triticum monococcum L. ssp. monococcum, cv. Monlis) were sown in plastic trays $(0.36 \mathrm{~m} \times 0.22 \mathrm{~m}, 40 \mathrm{~mm}$ high) filled with washed and dried quartz sand (3.5 kg per tray) at the crop density of 400 seeds per tray. Trays were irrigated with an excess of Hoagland's solution diluted two times. After dripping, the tray held $960 \pm 14 \mathrm{~g}$ of solution, corresponding to a field capacity of $38.0 \pm 0.6 \%(v / v)$. Trays were then placed into a growth chamber under controlled conditions ( $\mathrm{T}=20 \pm 1{ }^{\circ} \mathrm{C}$, relative humidity $(\mathrm{RH})=70 \pm 5 \%$ ) and kept in the dark until the emergence (i.e., coleoptile tips becoming visible), Zadoks' 10 [21], which occurred $72 \mathrm{~h}$ after sowing. 
Afterwards, the plants were exposed to different light spectra, all having a constant photon flux density (PFD) of $200 \pm 20 \mu \mathrm{mol} \mathrm{m}^{-2} \mathrm{~s}^{-1}$ and 14/10 h light/dark photoperiod, using the LED lamps described in Tosti et al. [22]. According to a completely randomized design with two replicates (trays), we applied six different combinations of blue (400-500 nm wavelength band), red (500-600 nm), and intermediate wavelengths $(500-600 \mathrm{~nm})$, namely, blue monochromatic with a peak at $450 \mathrm{~nm}$ (B100); red monochromatic with a peak at $656 \mathrm{~nm}$ (R100); blue/red dichromatic that was 75\% blue and $25 \%$ red (B75R25), 50\% blue and 50\% red (R50B50), and 25\% blue and 75\% red (B25R75); and a wide spectrum (WIDE) as a control treatment, composed of $18 \%$ blue, $18 \%$ red, and $64 \%$ intermediate wavelength, with a peak at $520 \mathrm{~nm}$ (Figure 1).

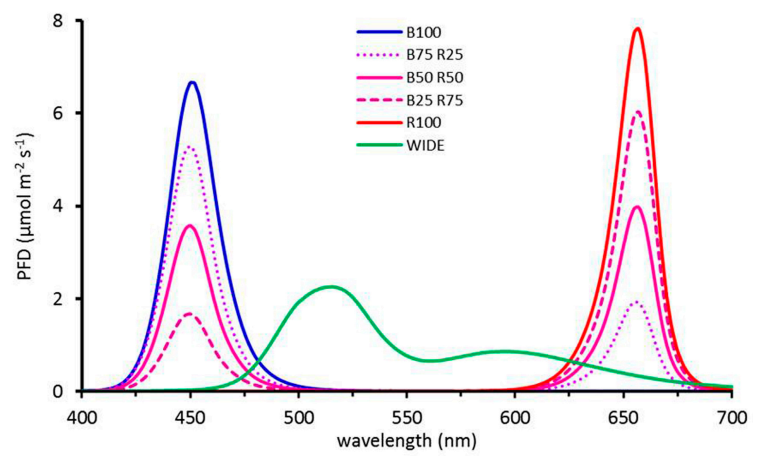

Figure 1. Light spectra in the six experimental light treatments. Photon flux densities (PFD) were recorded by a LI-180 spectrometer (LI-COR inc., Nebraska, NE, USA).

Trays were sub-irrigated three times a week during the entire crop cycle to restore the water-holding capacity of the substrate.

\subsection{Measurements}

All measurements were carried out 18 days after emergence (DAE) when plants reached Zadoks' stage 12 (collar of second leaf visible).

\section{3. $\mathrm{CO}_{2}$ Gas Exchanges and Growth Parameters of Seedlings}

The $\mathrm{CO}_{2}$ gas exchange was determined for each tray using an original glass chamber of $24 \mathrm{~L}$ of internal volume connected to an infrared gas analyzer (IRGA) from an ADC-LAC3 system (Delta $\mathrm{T}$ devices, United Kingdom), assembled to run as a closed system. The air leaving the chamber was passed through a drier column before entering the LCA3 IRGA. The $\mathrm{CO}_{2}$ concentration inside the chamber was recorded every $30 \mathrm{~s}$ for approximately $10 \mathrm{~min}$, starting $5 \mathrm{~min}$ after placing the chamber over the tray. Then, the chamber was covered with a black envelope and, after $5 \mathrm{~min}$, the $\mathrm{CO}_{2}$ concentration was recorded every $30 \mathrm{~s}$ for approximately $10 \mathrm{~min}$. The net $\mathrm{CO}_{2}$ assimilation rate $\left(\mathrm{A}_{\text {net }}\right)$ and the respiration rate in the dark $\left(\mathrm{R}_{\mathrm{d}}\right)$ were calculated as the angular coefficient of the first order regressions " $\mathrm{CO}_{2}$ concentration vs. time" in the light and dark, respectively. The regressions were calculated within the $\mathrm{CO}_{2}$ concentration in the range $380-480 \mathrm{ppm}$ for both assimilation and respiration. For all measurements, the goodness of the regression was always very high, i.e., $R^{2}>0.98$.

On DAE18, the trays were irrigated and weighted at the beginning and the end of the light period. The average evapotranspiration rate was calculated as the weight loss over the $14 \mathrm{~h}$, considering the increase in plant biomass weight due to net assimilation being negligible. Immediately after this, side and top pictures of each tray outside of the lamps were taken, and shoots and below-ground parts (i.e., roots and grain residues) were harvested. Shoots were cut at the base and the below-ground parts were carefully harvested and washed. Subsamples of both plant portions were immediately stored at $-20^{\circ} \mathrm{C}$, while the remaining subsamples were oven-dried at $60^{\circ} \mathrm{C}$ for $72 \mathrm{~h}$. The shape (length and width) of the first leaf blade was measured for 20 individuals, randomly chosen for each tray. The leaf area was determined using a leaf area meter (Delta-T Devices Ltd., Cambridge, UK). 


\subsection{Content of Chlorophylls and Carotenoids}

Chlorophyll (Chl-a and Chl-b) and carotenoid determinations were performed on shoots. Samples of the shoot tissue (1.5 g of fresh weight (FW ) per tray) were extracted in a mortar, using a pestle, with $85 \%(v / v)$ acetone, adding small amounts of sand of quartz. The resulting suspension was then filtered, and the absorbance (A) was determined spectrophotometrically at 452.5, 644, and $663 \mathrm{~nm}$, according to Metzner et al. [23].

\subsection{Nutrient Concentrations in Shoots}

All the nutrient determinations were carried out on shoot samples dried at $\pm 60{ }^{\circ} \mathrm{C}$ until a constant weight was reached. For each sample, we carried out chemical analyses in duplicate.

Nitrogen quantification was carried out on shoot $(1.0 \mathrm{~g})$ acid digested with $12.5 \mathrm{~mL}$ of $\mathrm{H}_{2} \mathrm{SO}_{4}$ $96 \%(v / v), 7.0 \mathrm{~mL}$ of $\mathrm{H}_{2} \mathrm{O}_{2} 30 \%(v / v)$, and one Kjeldahl tablet. After cooling, samples were added with $80.0 \mathrm{~mL}$ of $\mathrm{NaOH} 32.5 \%(w / v)$. Total nitrogen $(\mathrm{N})$ was determined by titration with $\mathrm{H}_{2} \mathrm{SO}_{4} 0.1 \mathrm{~N}$, according to Kjeldahl [24]. For sulfur determination, dried shoots $(1.0 \mathrm{~g})$ were digested with 9:4 $\mathrm{HNO}_{3}$ $96 \%(v / v)$ and $\mathrm{HClO}_{4} 70 \%(v / v)$. Then, $\mathrm{S}$ concentration was determined by using barium chloride gelatin turbidimetric assay, according to Tabatabai and Bremner [25]. A total of $0.25 \mathrm{~g}$ of shoots were added to $7.0 \mathrm{~mL}$ of $\mathrm{HNO}_{3} 65 \%(v / v)$ and $3.0 \mathrm{~mL}$ of $\mathrm{H}_{2} \mathrm{O}_{2} 30 \%(v / v)$ and were digested at $90{ }^{\circ} \mathrm{C}$. Suspensions were then filtered, and $\mathrm{P}, \mathrm{K}, \mathrm{Ca}, \mathrm{Mg}, \mathrm{Na}, \mathrm{Fe}, \mathrm{Mn}, \mathrm{Zn}$, and $\mathrm{Cu}$ were quantified by Inductively Coupled Plasma (ICP) spectrometry [26].

\subsection{Statistical Analysis}

The effect of treatments was evaluated by one-way analysis of variance according to a randomized block design with two replicates $(n=2)$. The basic assumptions for ANOVA were tested by using graphical analysis of residuals. In the case of significance of the $F$-test $(p<0.05)$, we carried out pairwise comparisons among means on the basis of the Tukey's HSD (Honest Significant Difference) by using the "emmeans" package in the R statistical environment [27].

\section{Results}

\subsection{Gas Exchange in Einkorn Seedlings at Zadoks' 12}

Significant differences in $A_{\text {net }}$ were recorded between the high value of B25R75 and the low values of B100, R100, and WIDE. A non-significant decrease of $A_{\text {net }}$ was observed in dichromatic treatments with increasing blue/red ratio. Differences among light treatments in dark respiration were found to be negligible and never significant (Table 1).

Table 1. Net assimilation, dark respiration, and evapotranspiration of einkorn seedlings at Zadoks' 12. SEM: pooled standard error of the mean. ${ }^{* *}$ and ${ }^{* *}$ indicate that the values are significantly different for $p<0.01$ and $p<0.001$, respectively; n.s. indicates that the values are not significantly different. Means followed by the same letter are not different for $p<0.05$ (Tukey's HSD test).

\begin{tabular}{|c|c|c|c|}
\hline \multirow{2}{*}{ Treatment } & Net Assimilation & Dark Respiration & ET Rate \\
\hline & $\mu \mathrm{mol} \mathrm{CO} \mathrm{CO}_{2} \mathrm{~m}^{-2} \mathrm{~s}^{-1}$ & $\mu \mathrm{mol} \mathrm{CO} \mathrm{Cm}^{-2} \mathrm{~s}^{-1}$ & $\mathrm{mmol} \mathrm{H}_{2} \mathrm{O} \mathrm{m}^{-2} \mathrm{~s}^{-1}$ \\
\hline B100 & $8.21^{b}$ & 10.58 & $5.82^{b}$ \\
\hline B75R25 & $9.31^{\mathrm{a}, \mathrm{b}}$ & 10.17 & $6.53^{\mathrm{ab}}$ \\
\hline B50R50 & $9.49^{\mathrm{a}, \mathrm{b}}$ & 10.44 & $6.78^{\mathrm{a}}$ \\
\hline B25R75 & $10.54^{\mathrm{a}}$ & 10.59 & $6.44^{\mathrm{ab}}$ \\
\hline $\mathrm{R} 100$ & $8.02^{b}$ & 9.39 & $4.48^{\mathrm{c}}$ \\
\hline WIDE & $8.72^{b}$ & 10.18 & $6.13^{\mathrm{ab}}$ \\
\hline SEM & 0.276 & 0.258 & 0.165 \\
\hline$F$-test & $* *$ & n.s. & $* * *$ \\
\hline
\end{tabular}

The ET was significantly the lowest in R100, while it varied within less than $1 \mathrm{mmol} \mathrm{H}_{2} \mathrm{O} \mathrm{m}^{-2} \mathrm{~s}^{-1}$ for the other treatments, with only the difference between B100 and B50R50 being significant. 


\subsection{Crop Yield and Biomass Partitioning}

Light spectrum significantly affected whole plant biomass production (Figure 2), which varied between $459 \pm 10 \mathrm{~g} \mathrm{~m}^{-2}$ in B25R75 and $400 \pm 4 \mathrm{~g} \mathrm{~m}^{-2}$ in B100.

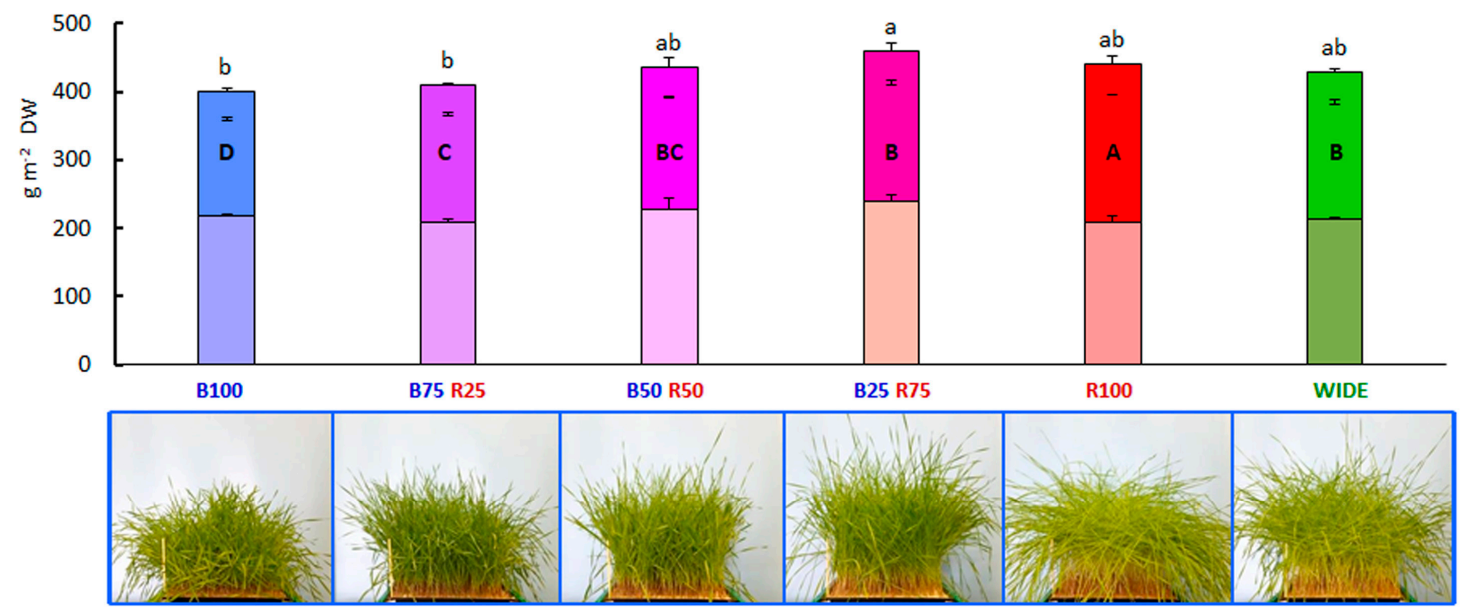

Figure 2. Upper histogram: whole plant biomass yield and biomass partitioning between shoots, (upper bars) and below-ground parts (bottom bars). Means followed by the same letters are not statistically different for $p<0.05$ (Tukey's HSD test)—small letters refer to significance for whole plant biomass, capital letters refer to significance of shoot biomass. Letters for below-ground biomass were omitted as the effect of treatments was not significant. Error bars represent +1 SEM for whole plant (top), shoot (middle), and below-ground (bottom) biomass. Lower pictures: side views of seedlings at Zadoks' 12.

Treatments differed only for shoot yield (SY), while root biomass was unaffected (range 210-240 $\mathrm{g} \mathrm{m}^{-2}$, pooled standard error of the mean (SEM) $=8.9$, n.s.). The highest SY was observed in R100 $\left(231 \pm 0.6 \mathrm{~g} \mathrm{~m}^{-2}\right)$ and the lowest one in B100 $\left(183 \pm 1.7 \mathrm{~g} \mathrm{~m}^{-2}\right)$. SY was found to decrease in dichromatic treatments, with increasing proportions of blue photons (SY $=-0.399 \mathrm{Blue} \%+229$, $\left.R^{2}=0.948\right)$. SY in WIDE was similar to that of B50R50 and B25R75.

The canopy architecture was strongly affected by light treatments (Figure 2, bottom). It was denser and shorter with higher proportions of blue, whereas the canopies appeared disheveled and pale green in R100 and WIDE.

\subsection{Leaf Morphology}

Treatments did not significantly affect the average leaf area (range $5.6-6.9 \mathrm{~cm}^{2}$, SEM $=0.38$ ), but they greatly affected the leaf shape (Table 2).

Table 2. Dimensions of the first leaf $(\mathrm{cm})$. SEM: pooled standard error of the mean. * and ** indicate that the values are significantly different for $p<0.05$ and $p<0.01$, respectively. Means followed by the same letter are not different for $p<0.05$ (Tukey's HSD test).

\begin{tabular}{ccc}
\hline \multirow{2}{*}{ Treatment } & Leaf Length & Leaf Width \\
\cline { 2 - 3 } & & $\mathbf{c m}$ \\
\hline B100 & $19.0^{\mathrm{c}}$ & $2.95^{\mathrm{a}}$ \\
B75R25 & $23.7^{\mathrm{b}}$ & $2.28^{\mathrm{a}, \mathrm{b}}$ \\
B50R50 & $24.3^{\mathrm{b}}$ & $2.40^{\mathrm{a}, \mathrm{b}}$ \\
B25R75 & $26.6^{\mathrm{b}}$ & $2.37^{\mathrm{a}, \mathrm{b}}$ \\
R100 & $34.5^{\mathrm{a}}$ & $1.83^{\mathrm{b}}$ \\
WIDE & $31.2^{\mathrm{a}}$ & $2.20^{\mathrm{a}, \mathrm{b}}$ \\
SEM & 0.54 & 0.184 \\
F test & $* *$ & $*$ \\
\hline
\end{tabular}


In R100 and WIDE leaves were the longest, followed by those of dichromatic treatments and then by those of B100. Leaf width in R100 was significantly lower than in B100, while each of these two treatments did not differ significantly from dichromatic treatments and WIDE.

\subsection{Photosynthetic Pigments in Shoots}

Figure 3 shows the contents of chlorophyll $a$ and $b$, and carotenoids found in einkorn shoot samples subjected to six different light treatments.
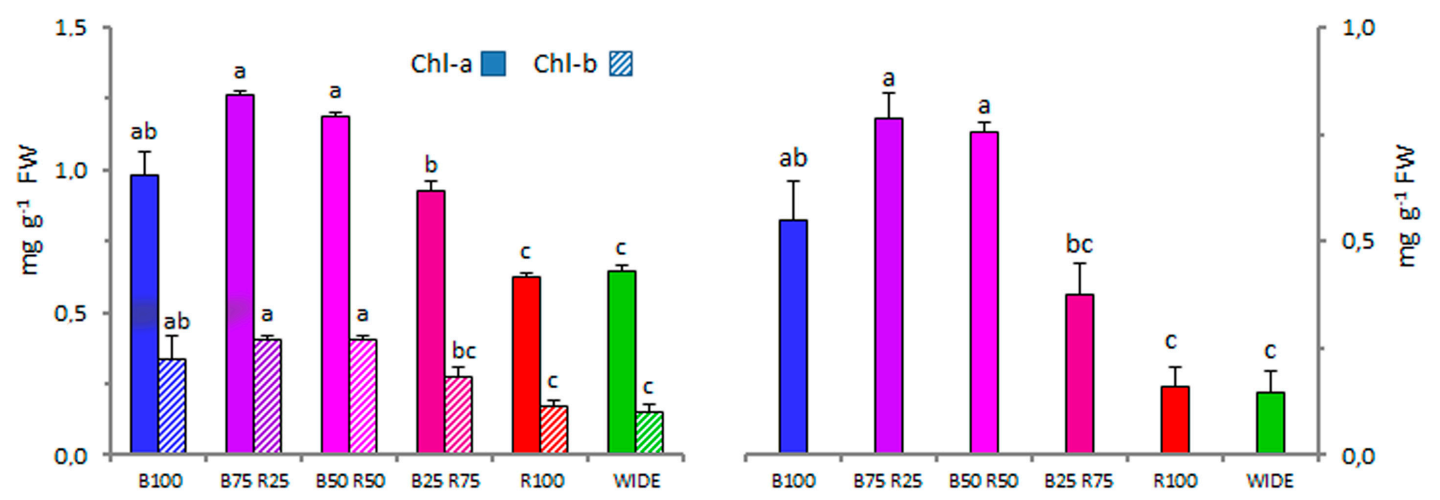

Figure 3. Chlorophyll (left) and carotenoid (right) content in einkorn shoots subjected to six light treatments. Means followed by the same letters are not statistically different for $p<0.05$ (Tukey's HSD test). Errors bars represent +1 SEM.

Chl-a, B75R25, and B50R50 determined the highest increases in the pigment content. B100 exerted an effect statistically comparable to the abovementioned treatments. Contrarily, significant decreases of Chl-a were found in B25R75 and, in particular, in R100 and WIDE, when compared to B75R25 and B50R50. As for Chl-b, a similar trend was ascertained. In particular, B100, B75R25, and B50R50 raised the content of this pigment, even though they did not statistically differ from each other. The other light combinations decreased the content of Chl-b in the following order: B25R75 > R100 > WIDE. As for carotenoids, it was found that the treatments B75R25 and B50R50 sharply increased the pigments' concentration. In addition, under B100, the content of carotenoids was not significantly different from the abovementioned treatments. The carotenoid drop was found to be higher in B25R75 and more severe under R100 and WIDE.

\subsection{Nutrient Content}

Table 3 illustrates the content of macro- and micronutrients ascertained in einkorn wheatgrass subjected to different light treatments.

For N, the highest content was found in samples treated with B100, B75R25, and B50R50. Differently, the nutrient content was found to be lower in B25R75 and WIDE than in B100. On the other hand, R100 showed a more marked decrease in $\mathrm{N}$ content.

As for $\mathrm{P}$, the highest content of the nutrient was found in the samples grown in the presence of B50R50, B75R25, B100, and B25R75. Differently, the P content started to significantly decrease when einkorn was exposed to R100 and WIDE.

$\mathrm{Mg}$ reached the highest values in samples exposed to B50R50, B75R25, and B25R75. Thereafter, all the other treatments reduced the content of this nutrient when compared to B50R50, following the order B100, R100, and then WIDE.

As for Fe, the highest nutrient content was found in B50R50, B75R25, B25R75, and B100. R100 and WIDE showed significant reductions in iron content when compared to other treatments (Table 3).

For $\mathrm{Zn}$, the highest content was recorded in plants exposed to B50R50, B100, B75R25, and WIDE. In contrast, B25R75 and R100 exerted a progressively decreasing effect on the content of this nutrient when compared to B50R50. 
Regarding the contents of $\mathrm{S}, \mathrm{K}, \mathrm{Ca}, \mathrm{Na}, \mathrm{Mn}$, and $\mathrm{Cu}$, we found differences among the different light treatments to not be statistically significant.

Table 3. Shoot content of mineral elements found in einkorn plants grown under six different light treatments. Means followed by the same letters are not statistically different for $p<0.05$ (Tukey's HSD test). SEM: pooled standard error of the mean. ${ }^{*}$ and ${ }^{* *}$ indicate that the values are significantly different for $p<0.05$ and $p<0.01$, respectively; n.s. indicates that the values are not significantly different.

\begin{tabular}{|c|c|c|c|c|c|c|c|c|c|c|c|}
\hline \multirow{2}{*}{ Treatment } & $\mathbf{N}$ & $\mathbf{P}$ & S & $\mathbf{K}$ & $\mathrm{Ca}$ & $\mathrm{Mg}$ & $\mathrm{Na}$ & $\mathrm{Fe}$ & Mn & $\mathrm{Zn}$ & $\mathrm{Cu}$ \\
\hline & \multicolumn{6}{|c|}{$\mathrm{mg} \mathrm{g}^{-1} \mathrm{DW}$} & \multicolumn{5}{|c|}{$\mu \mathrm{g} \mathrm{g}^{-1} \mathrm{DW}$} \\
\hline B100 & $38.8^{a}$ & $3.22^{a, c}$ & 2.32 & 8.27 & 1.69 & $0.590^{b, c}$ & 0.130 & $38.1^{\mathrm{a}, \mathrm{c}}$ & 26.2 & $41.8^{a, b}$ & 4.55 \\
\hline B75R25 & $37.0^{\mathrm{a}, \mathrm{b}}$ & $3.90^{a, b}$ & 2.32 & 7.96 & 1.35 & $0.654^{\mathrm{a}, \mathrm{b}}$ & 0.108 & $45.2^{\mathrm{a}, \mathrm{b}}$ & 33.2 & $40.2^{\mathrm{a}, \mathrm{b}}$ & 4.69 \\
\hline B50R50 & $36.3^{a, b}$ & $4.47^{\mathrm{a}}$ & 2.37 & 7.62 & 1.66 & $0.792^{\mathrm{a}}$ & 0.110 & $46.7^{\mathrm{a}}$ & 27.5 & $58.8^{\mathrm{a}}$ & 5.48 \\
\hline B25R75 & $31.6^{\mathrm{b}, \mathrm{c}}$ & $3.06^{a, c}$ & 2.15 & 7.05 & 1.29 & $0.618^{a, c}$ & 0.097 & $39.8^{a, b}$ & 26.2 & $25.0^{\mathrm{b}}$ & 5.09 \\
\hline R100 & $28.8^{c}$ & $2.96^{b, d}$ & 2.22 & 6.70 & 1.35 & $0.578^{b, c}$ & 0.114 & $30.2^{b, c}$ & 24.8 & $22.0^{\mathrm{b}}$ & 4.09 \\
\hline WIDE & $31.9^{b, c}$ & $1.58^{\mathrm{d}}$ & 2.51 & 5.90 & 1.23 & $0.463^{c}$ & 0.106 & $24.1^{\mathrm{c}}$ & 17.0 & $30.7^{a, b}$ & 3.49 \\
\hline Pooled SEM & 0.98 & 0.242 & 0.19 & 0.481 & 0.209 & 0.0313 & 8.5 & 2.60 & 2.61 & 4.73 & 0.40 \\
\hline$F$-test & $* *$ & $* *$ & n.s & n.s. & n.s & $* *$ & n.s & $* *$ & n.s. & * & n.s. \\
\hline
\end{tabular}

\section{Discussion}

The effect of the light spectrum depends on the plant species and genotype $[12,28]$. Our results indicate that $A_{\text {net }}$ in einkorn seedlings was high in the presence of dichromatic light and that monochromatic treatments, particularly the red light, tended to reduce the $\mathrm{CO}_{2}$ net assimilation. These results are in line with the evidence obtained for cucumber, tomato, and chrysanthemum plantlets [29-31], and with the work of Huché-Thelier et al. [12], who reported that blue (similarly to our B100) or red light alone (similarly to our R100) reduced the photosynthetic activity. To explain this behavior, it should be considered that blue light has a lower relative quantum efficiency compared to red light, due to the modest capacity of the pigments to absorb blue and transfer energy (i.e., carotenoids). Furthermore, such an effect could be due to those pigments that are unable to perceive blue light (i.e., anthocyanins) [32]. On the other hand, Dueck et al. [33] reported that prolonged exposure of the species to red light alone could worsen their photosynthetic performance. A similar effect was also reported by Dong et al. [34]. These authors found that in wheat seedlings under red light, the increasing length of epidermal cells between stomata led to a lower stomata density per unit leaf area, causing a reduction in the $\mathrm{CO}_{2}$ assimilation.

The low photosynthetic rate of the polychromatic treatment (WIDE) was not expected, on the basis of the high density of the canopy and light spectrum. In fact, due to the high proportion of intermediate wavelengths, the overall light color tended to green. Some authors reported that in dense canopies, green light drives photosynthesis of lower canopy layers because this color can pass through the upper layers [35]. However, the einkorn seedlings showed a markedly erectophile canopy, and thus a light penetration into the lower leaf layers was also possible for the blue and red wavelengths. Thus, our data are consistent with experiments conducted in growth chambers, where wheat photosynthesis was enhanced in the presence of blue light [36].

Dark respiration accounted for 53\% (SEM \pm 1.5$)$ of gross photosynthesis on average. Such a value is higher than that reported by Gifford [37], who found that the ratio of respiration to gross photosynthesis (R:P) was relatively constant in wheat $(0.40-0.45)$. However, when the remobilization of carbon reserves from storage organs is still occurring, as in the case of young seedlings, the R/P ratio could reach higher values [38].

The evaporation depends on the photon's energy, which, according to Planck's law, is inversely proportional to the radiation wavelength. Thus, given the same total PPFD for all treatments, the monochromatic blue light was expected to promote the highest water consumption. In contrast, ET values were low in B100, significantly lower than in B50R50, although not as low as in R100. Such an effect can be explained by considering the stomatal conductance, which has been found to be higher in the case of dichromatic blue/red light [39]. 
Data on shoot yield and leaf shape as a function of light treatment appear in line with evidence obtained for several other species and einkorn wheatgrass [18,22,36,40]. Red and blue light are confirmed to have opposite effects. As far as root length is concerned, the lack of difference observed in our experiment would seem to conflict with results by Benincasa et al. [18], who found that the monochromatic red light significantly increased root length. However, in that experiment, seeds were sprouted on sterile cotton, exposing root to the direct light. Differently, in our experiment, the roots grew in a $40 \mathrm{~mm}$ sand layer, which protected them from the direct light. Since differences among treatments in root biomass were not significant, the monochromatic blue significantly reduced the shoot/root ratio compared to monochromatic red. This result is in agreement with findings of Johkan et al. [40] in lettuce seedlings. The effects of light spectra on vegetative plant growth are consistent with the literature for adult plants reviewed by Demotes-Mainard et al. [28] and Huché-Thélier et al. [12]. In particular, blue light is necessary for photomorphogenesis, involving cryptochromes and phototropins, and reduces cell expansion and promotes a certain plant dwarfing $[10,16,22,40]$. On the other hand, red light causes pseudo-stem elongation in wheatgrass and favors leaf elongation in wheat, like in many vegetable crops $[16,18,22,36,40]$. Moreover, such long leaves prostrated, losing the erectophile arrangement (Figure 2). For these reasons, ground cover and light absorption determined cumulative effects during the entire growing period, with the main factors affecting seedlings grown under monochromatic red light, therefore explaining the highest shoot yield recorded at harvesting (DAE 18, Zadoks' 12).

Differences in the light spectra can influence the content of chlorophylls and other pigments due to the plant's capacity to sense small variations in the quality of energy through photoreceptors [41]. Of these photoreceptors, phytochromes are red light sensors, capable of promoting seed germination and flowering. Cryptochromes and phototropins respond mainly to blue light and regulate the circadian rhythms, pigment biosynthesis, and the relocation of chloroplasts [42]. Moreover, chlorophylls show maximum light absorption in the blue and red regions [43]. For this reason, there is a profound connection between their content and the light spectrum [44].

Figure 3 shows the effect of the different light treatments on the content of chlorophylls and carotenoids. As for Chl-a and Chl-b, the increase in the blue fraction raised the content of these pigments, and B75R25 and B50R50 were the most effective combinations. Differently, the chlorophyll content decreased by progressively increasing the red fraction to $100 \%$. Finally, the einkorn treated with WIDE showed an exceptionally low content of chlorophylls, as a consequence of the different components of its spectra. In particular, WIDE had the lowest content of blue, which was $18 \%$, compared to the dichromatic treatments. Therefore, WIDE and R100, for the smaller or missing blue fraction, were less effective than the other light treatments in inducing the cryptochrome-mediated responses. Such an effect led to decreases in the content of the Chl-a and Chl-b. On the basis of our data, we conclude that a fraction of blue of $50 \%$ or higher positively affects the chlorophyll content in einkorn seedlings.

Despite these results, it should be noted that the literature indicates that the effect of light spectra on chlorophylls can vary between species, showing completely different responses. This behavior is due to light spectra that, depending on its composition, can inactivate or activate photoreceptors, and their co-action is generally unpredictable and can be synergistic or antagonistic [45]. However, the stimulatory effect of the blue on the chlorophyll content, particularly when in combination with red, has been ascertained by some authors for spinach, radish, and lettuce $[29,42,46]$. These findings can be explained by considering the effect of blue light on cryptochromes, which in some species consists of the induction of the chlorophylls' biosynthesis and chloroplast development. Kasahara et al. [47] pointed out that the blue light can also promote the organization of chloroplasts, inducing their movement toward the cell surface to increase their efficiency [48]. Similarly, Liu et al. [30] pointed out that blue light is necessary for the optimal development of the chloroplast in cherry tomato since, under red light alone, chloroplasts can have scattered grana and vague lamellae structure. 
Particular attention deserves the question of how the composition of the spectra can affect the content of carotenoids since they are considered secondary metabolites of importance for human nutrition. Carotenoids can exert protective actions against cancer, cardiovascular diseases, and age-related macular degeneration [49]. Carotenoids, classifiable as lipophilic tetraterpenoid pigments, act in plants as photosensitizers and face oxidative perturbation, scavenging reactive oxygen species (ROS) [50]. Moreover, carotenoids harvest and transmit the light energy to chlorophylls [51]. Our experiments showed that the treatments with dichromatic lights, having an equal proportion of blue and red (B50R50) or a predominant fraction of blue (B75R25), greatly affected the content of these pigments. Contrarily, higher fractions of red light exerted an opposite effect, reducing the carotenoid content in einkorn shoots. Finally, WIDE showed a similar trend to R100. The stimulatory effect of the blue light on carotenoid content can be related to its specific action on photoreceptors. In particular, it has been documented that blue light, through cryptochromes, regulates a variety of physiological and biochemical functions in plants [6]. Among these, stomatal opening, biosynthesis of anthocyanins, and carotenoids have been considered [17].

Indoor cultivation based on LED lights can improve the acquisition of nutrients by plants when compared to traditional growing systems. Therefore, the content of minerals in the edible tissues can be increased with the composition of the light spectra [3]. This aspect is of fundamental importance for the repercussions on human health due to the consumption of vegetables containing high nutrient values [52]. Our experiments showed that the dichromatic lights, particularly with blue and red in equal proportion, or with a higher fraction of blue, generally increased the content of $\mathrm{N}, \mathrm{P}, \mathrm{Mg}, \mathrm{Fe}$, and $\mathrm{Zn}$ in einkorn wheatgrass (Table 3). As for monochromatic lights, blue was particularly effective in increasing the N plant content, while red light reduced it. WIDE negatively influenced the ability of einkorn to acquire nutrients, with the only exception of $\mathrm{Zn}$ (Table 3). These results highlight, as in the case of chlorophylls and carotenoids, the beneficial effect of the blue component of the light spectra. However, it is to be emphasized that low contents of blue and red in the spectra, and high content of intermediate wavelengths, as in the case of WIDE, generally resulted in a dramatic loss of nutrients (Table 3). Similar effects on plant nutrition have been reported for shoot tissues of broccoli microgreens, where the exposition to blue light increased the content of $\mathrm{P}, \mathrm{Mg}, \mathrm{Mn}, \mathrm{Zn}$, and Fe [43]. Such an effect was associated with increased transpiration and stomatal conductance. Furthermore, blue light has been reported to increase the content of $\mathrm{K}$ and $\mathrm{Ca}$ in lettuce, while a combination of blue and red enhanced the content of N, P, Mg, and Fe [53]. Pinho et al. [54] investigated the effect of four LED light spectral combinations on lettuce. The authors found that LED lights stimulated plant growth and the uptake of $\mathrm{K}, \mathrm{Ca}$, and $\mathrm{Mg}$ when compared to traditional high-pressure sodium lighting [54]. Furthermore, the spectral changes of the red and blue lights influenced the uptake of Fe and Zn [54]. Another study investigated the effects of the red and blue spectral components in lettuce [55]. In this case, a predominant fraction of the red raised the concentration of N, P, K, and $\mathrm{Mg}$ in lettuce leaves. Finally, Pennisi et al. [3] found that the mineral nutrient content in basil was particularly increased when the red/blue ratio was 3 . However, the authors underlined that the limited number of studies and the variability in the experimental designs do not allow for the finding of a right combination of blue and red that could guarantee an optimal nutrient uptake for all species.

\section{Conclusions}

In conclusion, this work demonstrated the feasibility of growing einkorn, using different proportions of blue and red lights, in a substrate containing a nutritive solution. We showed how all the light treatments investigated affected gas exchange, plant morphology, growth, pigment content, and nutrient absorption. As a general trend, we found that dichromatic treatments had a positive impact on some pivotal physiological aspect of the seedlings (net $\mathrm{CO}_{2}$ assimilation, evapotranspiration, and biomass), the content of pigments (chlorophylls and carotenoids), and mineral nutrients ( $\mathrm{N}, \mathrm{P}, \mathrm{Mg}$, $\mathrm{Fe}$, and $\mathrm{Zn}$ ). These results are remarkable since high contents of pigments and minerals could have an outstanding nutritional value. 
Author Contributions: Conceptualization, M.G., D.D.B., P.B.; methodology, D.D.B., M.L.B., E.B., P.B., B.F., M.G.; formal analysis, M.G.; investigation, M.L.B., E.B., D.D.B., B.F.; resources, P.B.; data curation, M.L.B., E.B., B.F., M.G.; writing-original draft preparation, D.D.B., M.G.; writing-review and editing, D.D.B., P.B., M.G.; supervision, M.G., D.D.B.; project administration, M.G., D.D.B.; funding acquisition, P.B. All authors have read and agreed to the published version of the manuscript.

Funding: This research was funded by the Project "Ricerca di Base 2018-2020" of the Department of Agricultural, Food and Environmental Sciences of the University of Perugia (Coordinator: Paolo Benincasa).

Acknowledgments: We gratefully acknowledge GNC s.r.l. for providing the LED lamps, Massimo Fiorani (Prometeo s.r.l.) for providing grains, and Silvano Locchi and Rossano Cortona for technical assistance in the seed lab.

Conflicts of Interest: The authors declare no conflict of interest.

\section{References}

1. Dou, H.; Niu, G.; Gu, M.; Masabni, J.G. Responses of sweet basil to different daily light integrals in photosynthesis, morphology, yield, and nutritional quality. HortScience 2018, 53, 496-503. [CrossRef]

2. Del Buono, D.; Terzano, R.; Panfili, I.; Bartucca, M.L. Phytoremediation and detoxification of xenobiotics in plants: Herbicide-safeners as a tool to improve plant efficiency in the remediation of polluted environments. A mini-review. Int. J. Phytorem. 2020, 21, 1-15. [CrossRef] [PubMed]

3. Pennisi, G.; Blasioli, S.; Cellini, C.; Maia, L.; Crepaldi, A.; Braschi, I.; Spinelli, F.; Nicola, S.; Fernandez, J.A.; Stanghellini, C.; et al. Unraveling the role of red:blue LED lights on resource use efficiency and nutritional properties of indoor grown sweet basil. Front. Plant Sci. 2019, 10, 305. [CrossRef] [PubMed]

4. Benincasa, P.; Falcinelli, B.; Lutts, S.; Stagnari, F.; Galieni, A. Sprouted grains: A comprehensive review. Nutrients 2019, 11, 421. [CrossRef] [PubMed]

5. Kyriacou, M.C.; Rouphael, Y.; Di Gioia, F.; Kyratzis, A.; Serio, F.; Renna, M.; De Pascale, S.; Santamaria, P. Micro-scale vegetable production and the rise of microgreens. Trends Food Sci. Technol. 2016, 57, $103-115$. [CrossRef]

6. Heo, J.; Lee, C.; Chakrabarty, D.; Paek, K. Growth responses of marigold and salvia bedding plants as affected by monochromic or mixture radiation provided by a Light-Emitting Diode (LED). Plant Growth Regul. 2002, 38, 225-230. [CrossRef]

7. Hasan, M.M.; Bashir, T.; Ghosh, R.; Lee, S.K.; Bae, H. An overview of leds' effects on the production of bioactive compounds and crop quality. Molecules 2017, 22, 1420. [CrossRef]

8. Akiyama, T.; Kozai, T. Light environment in the cultivation space of plant factory with LEDs. In LED Lighting for Urban Agriculture; Kozai, T., Fujiwara, K., Runkle, E.S., Eds.; Springer: Berlin, Germany, 2016; pp. 91-109.

9. Wang, J.; Lu, W.; Tong, Y.; Yang, Q. Leaf morphology, photosynthetic performance, chlorophyll fluorescence, stomatal development of lettuce (Lactuca sativa L.) exposed to different ratios of red light to blue light. Front. Plant Sci. 2016, 7, 250. [CrossRef]

10. Ouzounis, T.; Rosenqvist, E.; Ottosen, C. Spectral effects of artificial light on plant physiology and secondary metabolism: A review. HortScience 2015, 50, 1128-1135. [CrossRef]

11. van Ieperen, W. Plant morphological and developmental responses to light quality in a horticultural context. Acta Hortic. 2012, 956, 131-139. [CrossRef]

12. Huché-Thélier, L.; Crespel, L.; Le Gourrierec, J.; Morel, P.; Sakr, S.; Leduc, N. Light signalling and plant responses to blue and UV radiations-Perspectives for applications in horticulture. Environ. Exp. Bot. 2016, 121, 22-38. [CrossRef]

13. Wright, S.W.; Shearer, J.D. Rapid extraction and high-performance liquid chromatography of chlorophylls and carotenoids from marine phytoplankton. J. Chromatogr. A 1984, 294, 281-295. [CrossRef]

14. Liu, J.; Zhang, F.; Zhou, J.; Chen, F.; Wang, B.; Xie, X. Phytochrome B control of total leaf area and stomatal density affects drought tolerance in rice. Plant Mol. Biol. 2012, 78, 289-300. [CrossRef]

15. Whitelam, G.C.; Halliday, K. Light and plant development. In Annual Plant Reviews; Whitelam, G.C., Halliday, K., Eds.; Blackwell Publishing: Oxford, UK, 2007.

16. Olle, M.; Virsile, A. The effect of light-emitting diode lightning on greenhouse plant growth and quality. Agric. Food Sci. 2013, 22, 223-234. [CrossRef] 
17. Samuoliené, G.; Viršile, A.; Brazaityte, A.; Jankauskiene, J.; Sakalauskiene, S.; Vaštakaite, V.; Novičkovas, A.; Viškeliene, A.; Sasnauskas, A.; Duchovskis, P. Blue light dosage affects carotenoids and tocopherols in microgreens. Food Chem. 2017, 228, 50-56. [CrossRef] [PubMed]

18. Benincasa, P.; Tosti, G.; Farneselli, M.; Maranghi, S.; Bravi, E.; Marconi, O.; Falcinelli, B.; Guiducci, M. Phenolic content and antioxidant activity of einkorn and emmer sprouts and wheatgrass obtained under different radiation wavelengths. Ann. Agric. Sci. 2020. [CrossRef]

19. Benincasa, P.; Galieni, A.; Manetta, A.C.; Pace, R.; Guiducci, M.; Pisante, M.; Stagnari, F. Phenolic compounds in grains, sprouts and wheatgrass of hulled and non-hulled wheat species. J. Sci. Food Agric. 2015, 95, 1795-1803. [CrossRef] [PubMed]

20. Stagnari, F.; Galieni, A.; D'Egidio, S.; Falcinelli, B.; Pagnani, G.; Pace, R.; Pisante, R.; Benincasa, P. Effects of sprouting and salt stress on polyphenol composition and antiradical activity of einkorn, emmer and durum wheat. Ital. J. Agron. 2017, 12, 293-301. [CrossRef]

21. Zadoks, J.C.; Chang, T.T.; Konzak, C.F. A decimal code for the growth stages of cereals. Weed Res. 1974, 14, 415-421. [CrossRef]

22. Tosti, G.; Benincasa, P.; Cortona, R.; Falcinelli, B.; Farneselli, M.; Guiducci, M.; Onofri, A.; Pannacci, E.; Tei, F.; Giulietti, M. Growing lettuce under multispectralight- emitting diodes lamps with adjustable light intensity. Ital. J. Agron. 2018, 11, 57-62.

23. Metzner, H.; Rau, H.; Senger, H. Untersuchungen zur synchronisierbar kein einzelner pigment-mangelmutanten von chlorella. Planta 1965, 65, 186-194. [CrossRef]

24. Kjeldahl, J. A new method for the estimation of nitrogen in organic compounds. Z. Anal. Chem. 1883, 22, 366-382. [CrossRef]

25. Tabatabai, M.A.; Bremner, J.M. A simple turbidimetric method of determining total sulfur in plant material. Agron. J. 1970, 62, 805-806. [CrossRef]

26. Hansen, T.H.; de Bang, T.C.; Laursen, K.H.; Pedas, P.; Husted, S.; Schjoerring, J.K. Multielement plant tissue analysis using ICP spectrometry. In Plant Mineral Nutrients. Methods in Molecular Biology (Methods and Protocols); Maathuis, F., Ed.; Humana Press: Totowa, NJ, USA, 2013; Volume 953, pp. 121-141.

27. Lenth, R.V. Least-Squares Means: The R Package lsmeans. J. Stat. Softw. 2016, 69, 1-33. [CrossRef]

28. Demotes-Mainard, S.; Péron, T.; Corot, A.; Bertheloot, J.; Le Gourrierec, J.; Pelleschi-Travier, S.; Crespel, L.; Morel, P.; Huché-Thélier, L.; Boumaza, R.; et al. Plant responses to red and far-red lights, applications in horticulture. Environ. Exp. Bot. 2016, 121, 4-21. [CrossRef]

29. Hogewoning, S.W.; Trouwborst, G.; Maljaars, H.; Poorter, H.; van Ieperen, W.; Harbinson, J. Blue light dose-responses of leaf photosynthesis, morphology, and chemical composition of Cucumis sativus grown under different combinations of red and blue light. J. Exp. Bot. 2010, 61, 3107-3117. [CrossRef]

30. Liu, X.Y.; Guo, S.; Xu, Z.; Jiao, X.; Takafumi, T. Regulation of chloroplast ultrastructure, cross-section anatomy of leaves, and morphology of stomata of cherry tomato by different light irradiations of light-emitting diodes. HortScience 2011, 46, 217-221.

31. Kim, S.J.; Hahn, E.J.; Heo, J.W.; Paek, K.Y. Effects of LEDs on net photosynthetic rate, growth and leaf stomata of chrysanthemum plantlets in vitro. Sci. Hortic. 2004, 101, 143-151. [CrossRef]

32. Cope, K.R.; Snowden, M.C.; Bugbee, B. Photobiological interactions of blue light and photosynthetic photon flux: Effects of monochromatic and broad-spectrum light sources. Photochem. Photobiol. 2014, 90, 574-584. [CrossRef]

33. Dueck, T.A.; van Ieperen, W.; Taulavuori, K. Light perception, signaling and plant responses to spectral quality and photoperiod in natural and horticultural environments. Environ. Exp. Bot. 2016, 121, 1-150. [CrossRef]

34. Dong, C.; Fu, Y.; Liu, G.; Liu, H. Growth, photosynthetic characteristics, antioxidant capacity and biomass yield and quality of wheat (Triticum aestivum L.) exposed to LED light sources with different spectra combinations. J. Agron. Crop Sci. 2014, 200, 219-230. [CrossRef]

35. Brodersen, C.R.; Vogelmann, T.C. Do changes in light direction affect absorption profiles in leaves? Funct. Plant Biol. 2010, 37, 403-412. [CrossRef]

36. Goins, G.D.; Yorio, N.C.; Sanwo, M.M.; Brown, C.S. Photomorphogenesis, photosynthesis and seed yield of wheat plants grown under red light-emitting diodes (LEDs) with and without supplemental blue lighting. J. Exp. Bot. 1997, 48, 1407-1413. [CrossRef] [PubMed] 
37. Gifford, R.M. Whole plant respiration and photosynthesis of wheat under increased $\mathrm{CO}_{2}$ concentration and temperature: Long-term vs short-term distinctions for modelling. Glob. Chang. Biol. 1995, 1, 385-396. [CrossRef]

38. Van Oijen, M.; Schapendonk, A.; Höglind, M. On the relative magnitudes of photosynthesis, respiration, growth and carbon storage in vegetation. Ann. Bot. 2010, 105, 793-797. [CrossRef] [PubMed]

39. Assmann, S.M. Enhancement of the stomatal response to blue light by red light, reduced intercellular concentrations of $\mathrm{CO}_{2}$, and low vapour pressure differences. Plant Physiol. 1988, 87, 226-231. [CrossRef]

40. Johkan, M.; Shoji, K.; Goto, F.; Hahida, S.; Yoshihara, T. Effect of green light wavelength and intensity on photomorphogenesis and photosynthesis in Lactuca sativa. Environ. Exp. Bot. 2012, 75, 128-133. [CrossRef]

41. Kopsell, D.A.; Sams, C.E.; Morrow, R.C. Blue wavelengths from LED lighting increase nutritionally important metabolites in specialty crops. HortScience 2015, 50, 1285-1288. [CrossRef]

42. Hernández, R.; Kubota, C. Growth and morphological response of cucumber seedlings to supplemental red and blue photon flux ratios under varied solar daily light integrals. Sci. Hortic. 2014, 173, 92-99. [CrossRef]

43. Kopsell, D.A.; Sams, C.E. Increases in shoot tissue pigments, glucosinolates, and mineral elements in sprouting broccoli after exposure to short-duration blue light from light emitting diodes. J. Am. Soc. Hortic. Sci. 2013, 138, 31-37. [CrossRef]

44. Graham, T.; Yorio, N.; Zhang, P.; Massa, G.; Wheeler, R. Early seedling response of six candidate crop species to increasing levels of blue light. Life Sci. Space Res. 2019, 21, 40-48. [CrossRef] [PubMed]

45. Casal, J.J. Phytochromes, cryptochromes, phototropin: Photoreceptor interactions in plants. Photochem. Photobiol. 2000, 71, 1-11. [CrossRef]

46. Matsuda, R.; Ohashi-Kaneko, K.; Fujiwara, K.; Kurata, K. Analysis of the relationship between blue-light photon flux density and the photosynthetic properties of spinach (Spinacia oleracea L.) leaves with regard to the acclimation of photosynthesis to growth irradiance. Soil Sci. Plant Nutr. 2007, 53, 459-465. [CrossRef]

47. Kasahara, M.; Swartz, T.E.; Olney, M.A.; Onodera, A.; Mochizuki, N.; Fukuzawa, H.; Asamizu, E.; Tabata, S.; Kanegae, H.; Takano, M.; et al. Photochemical properties of the flavin mononucleotide binding domains of the phototropins from Arabidopsis, rice, and Chlamydomonas reinhardtii. Plant Physiol. 2002, 129, 762-773. [CrossRef] [PubMed]

48. Bondada, B.R.; Oosterhuis, D.M. Morphometric analysis of chloroplasts of cotton leaf and fruiting organs. Biol. Plant. 2003, 47, 281-284. [CrossRef]

49. Mayne, S.T. $\beta$-carotene, carotenoids, and disease prevention in humans. FASEB J. 1996, 10, 690-701. [CrossRef] [PubMed]

50. Alrifai, O.; Hao, X.; Marcone, M.F.; Tsao, R. Current review of the modulatory effects of LED lights on photosynthesis of secondary metabolites and future perspectives of microgreen vegetables. J. Agric. Food Chem. 2019, 67, 6075-6090. [CrossRef]

51. Polívka, T.; Frank, H.A. Molecular factors controlling photosynthetic light harvesting by carotenoids. Acc. Chem. Res. 2010, 43, 1125-1134. [CrossRef]

52. Bocchini, M.; Bartucca, M.L.; Ciancaleoni, S.; Mimmo, T.; Cesco, S.; Pii, Y.; Albertini, E.; Del Buono, D. Iron deficiency in barley plants: Phytosiderophore release, iron translocation, and DNA methylation. Front. Plant Sci. 2015, 6, 514. [CrossRef]

53. Amoozgar, A.; Mohammadi, A.; Sabzalian, M.R. Impact of light-emitting diode irradiation on photosynthesis, phytochemical composition and mineral element content of lettuce cv. Grizzly. Photosynthetica 2017, 55, 85-95. [CrossRef]

54. Pinho, P.; Jokinen, K.; Halonen, L. The influence of the LED light spectrum on the growth and nutrient uptake of hydroponically grown Lettuce. Light. Res. Technol. 2017, 49, 866-881. [CrossRef]

55. Pennisi, G.; Orsini, F.; Blasioli, S.; Cellini, A.; Crepaldi, A.; Braschi, I.; Spinelli, F.; Nicola, S.; Fernandez, J.A.; Stanghellini, C.; et al. Resource use efficiency of indoor lettuce (Lactuca Sativa, L.) cultivation as affected by red:blue ratio provided by LED lighting. Sci. Rep. 2019, 9, 14127. [CrossRef] [PubMed]

(C) 2020 by the authors. Licensee MDPI, Basel, Switzerland. This article is an open access article distributed under the terms and conditions of the Creative Commons Attribution (CC BY) license (http://creativecommons.org/licenses/by/4.0/). 